\title{
Особенности воспитания религиозной терпимости у студенческой молодежи в советский период (1917-1992 гг.)
}

\author{
Сахаров Василий А. \\ Кафедра Философии, Социологии и Психологии Вятский Государственный Университет \\ Россия \\ vas701@rambler.ru \\ Сахарова Людмила Г. \\ Кафедра Социальных Наук, Кировской Государственной Медицинской Академии \\ Россия \\ vas701rambler.ru
}

Sakharov V.A., Sakharova L.G., Features of education of religious tolerance among students during the Soviet period (1917-1992), Elpis, 17 2015: 93-102.

Сахаров В.А., Сахарова Л.Г., Charakterystyka edukacji tolerancji religijnej studentów w okresie sowieckim (1917-1992), Elpis, 17 2015: 93-102.

\begin{abstract}
The article analyses the problem of religious tolerance upbringing among youth. The search of effective methods of upbringing culture of interconfessional relations among modern student youth determinate the article urgency. The article also analyses concepts of religious tolerance and culture of interconfessional relations and the trends of state policy in this area.
\end{abstract}

\begin{abstract}
Streszczenie: Celem niniejszego artykułu jest analiza problemu edukacji religijnej tolerancji u młodzieży. Aktualność tej kwestii wynika z poszukiwaniem skutecznych metod wychowania, kultury, stosunków międzywyznaniowych u współczesnej młodzieży studenckiej. Analiza pedagogicznej teorii i praktyki pozwala wyjaśnić istotę pojęcia „tolerancja religijna” i „kultura stosunków międzywyznaniowych", odkryć uniwersalne sposoby realizacji polityki państwa w kwestii wychowania, kultury, stosunków międzywyznaniowych u młodzieży.

Аннотация: Целью данной статьи является анализ проблемы воспитания религиозной терпимости у молодежи. Актуальность изучения данного вопроса обусловлена поиском эффективных методов воспитания культуры межконфессиональных отношений у современной студенческой молодежи. Анализ педагогической теории и практики позволяет уточнить суть понятий «религиозная терпимость» и «культура межконфессиональных отношений», выявить универсальные способы реализации государственной политики по вопросу воспитания культуры межконфессиональных отношений у молодежи.
\end{abstract}

Keywords: culture of interconfessional relations, student youth, conception of culture of interconfessional relations upbringing, Russian pedagogic

Słowa kluczowe: kultura stosunków międzywyznaniowych, studencka młodzież, koncepcja edukacji kultury stosunków międzywyznaniowych, rosyjska pedagogika

Ключевые слова: культура межконфессиональных отношений, студенческая молодежь, концепция воспитания культуры межконфессиональных отношений, российская педагогика.

Коренные изменения всех сфер общественно-политической жизни в России после Октябрьской революции 1917 г. повлекли за собой изменение требования к подготовке специалистов в системе высшего образования. Советское государство взяло на себя задачу не только привести к коммунизму Россию, но и перестроить самого человека, его мышление, с тем, чтобы он был готов к созданию нового общества. Специалист с высшим образованием должен был играть важнейшую роль в развитии государства и нового общества.

Целью данной статьи является анализ особенностей воспитания религиозной терпимости у студенческой молодежи в условиях атеистической политики Советского государства.
Модернизации системы высшего образования в СССР на основе материалистических идей способствовал ряд социально-политических и исторических предпосылок:

- утверждение исключительно светского характера государственной власти и образования;

- курс на развитие у студенческой молодежи материалистического мировоззрения и атеистических установок;

- укрепление политики развития социального равенства и единства советского народа, независимо от национальной и религиозной принадлежности. Сохранение религиозного мировоззрения в молодежной среде мешало модернизационным процессам. 
Таким образом, одним из приоритетных направления деятельности высшей школы становится решение сложной педагогической задачи-это атеистическое воспитание студенческой молодежи, учитывающее необходимость формирования основ религиозной терпимости.

Определение цели воспитания основ религиозной терпимости вызывает определенные трудности, так как научного определения данному понятию в трудах ведущих советских педагогов мы не прослеживаем. Однако, на основе анализа идей советских педагогов мы сформулировали обобщенное понятие религиозной терпимости, характерной для советского периода: «Религиозная терпимость - это определенная государством социально-правовая норма поведения, не допускающая оскорблений чувств верующих (независимо от вероисповедания) при выраженной ориентация на развитие материалистического мировоззрения. На основе метода ретроспективного анализа постараемся воссоздать концепцию воспитания основ религиозной терпимости у студенческой молодежи в условиях развития атеистической идеологии.

Рассмотрим суть целевого, содержательного и результативного элементов воспитания веротерпимости в советский период. В трудах педагогов советского периода выделяются следующие основные целевые установки атеистического воспитания в русле формирования религиозной терпимости:

- формирование научного материалистического мировоззрения, атеистической сознательности (постепенное устранение религии из жизни общества снимает проблему возможности конфликтных ситуаций на религиозной почве) (радикальный подход: В.И. Ленин, Н.К. Крупская, А.А. Луначарский, Е.М. Ярославский и др.);

- развитие коллективизма, интернационализма как средства профилактики негативных проявлений на религиозной почве (разобщения, недоверия, профилактика действий оскорбительного плана между представителями различных религиозных групп, а также верующими и атеистами) (умеренный подход: П. П. Блонский, Я. Н. Бушуева, В. И. Гараджа, К. М. Левковский, А. С. Макаренко, А. Ф. Окулов, А. П. Пинкевич, М. Н. Покровский, С. Т. Шацкий, В. А. Сухомлинский и др.).

В качестве результата подготовки специалиста с высшим образованием в любой отрасли предусматривалась его готовность содействию в деле просвещения и модернизации советского общества. Обучение и воспитание верующей и неверующей студенческой молодежи, должны были осуществляться в соответствии с государственным заказом. В циркуляре ЦК РКП (б) «О работе парторганизаций в вузах и рабфаках» от 14 декабря 1922 г. основная суть его содержания была сформулирована следующим образом: «Значение высшей школы в настоящее время на боевом и культурном фронте огромно. Ее задачи - дать стране в кратчайшее время специали- стов по всем отраслям государственного строительства» ${ }^{1}[404$, с.272-273].

Количество высших учебных заведений, направленных на реализацию данной задачи, за первые три десятилетия советской власти в стране выросло почти в 8 раз: в 1914 г. - 105 вузов, в 1950 г.- 880 вузов.

«Положение о высших учебных заведениях в РСФСР» от 1922 г. устанавливало равный доступ граждан к высшему образованию независимо от вероисповедания и утверждало возможность приема в высшие учебные заведения всех граждан: «Студентами Высшего Учебного Заведения могут быть граждане обоего пола, достигшие 16-ти лет и удовлетворяющие правилам приема, установленным Народным Комиссариатом Просвещения. Студенты обязаны выполнять все требования учебного плана .

Значительная часть студенчества в первые годы советской власти была достаточно религиозной. Даже в оптимистичных отчетах советских идеологов атеизма отмечалось, что к концу 1920-х гг. от религии отошло примерно 20\% населения (А.В. Луначарский, Е.М. Ярославский и другие).

По данным переписи населения в СССР в 1937 году 38,3 \% населения в возрасте от 20 до 29 лет, считали себя верующими. Точная статистика числа верующих в студенческой среде в советский период отсутствует. Данные интервьюирования свидетельствуют, что верующие студенты вузов предпочитали не указывать себя таковыми ${ }^{2}$. Подтверждением сохранения элементов религиозности в рамках повседневной культуры студенческой молодежи являются характеристики особенностей внеаудиторной работы со студентами в советских вузах. Например, в характеристике работы кружка «Родиноведение» в Вятском педагогическои институте имени В.И. Ленина в начале 1920-х годов данный факт имел место: «Руководитель заметил членам кружка, что до Рождества работа была более или менее налажена, но после Рождества работа налаживалась как-то плохо» ${ }^{3}$

Высшие учебные заведения должны были организовать работу с различными группами студентов, верующими и атеистами, с учетом государственных установок на развитие основ религиозной терпимости. Молодым людям юношеского возраста, планировалось в первые десятилетия советской власти уделять особое внимание, так как в юношеский период происходит формирование мировоззрения.

Так, в Программе РКП (б), принятой на VIII съезде партии в марте 1918 года были даны рекомендации по организации атеистической работы с населением: «При

\footnotetext{
Циркуляр ЦК РКП(б) “О работе парторганизаций в вузах и рабфаках»С.272-273.

Жиромская В.Б. Религиозность народа в 1937 году (по материалам Всесоюзной переписи населения)//Исторический вестник. 2000. №5.-С.130-135.

3 Отчеты и доклады о работе научных и художественных кружков: протокол кружка «Родиноведение» (1920-1921 гг.)//Государственный архив Кировской области (ГАКО). Ф.Р-1148,Оп.1, Д. 77, Л.150.
} 
этом необходимо заботливо избегать всякого оскорбления чувств верующих, ведущего лишь к закреплению религиозного фанатизма» ${ }^{4}[42, \mathrm{c.135}]$.

Анализ теоретического и практического опыта педагогики высшей школы советского периода позволяет сделать вывод о том, что была выработана педагогическая концепция атеистического воспитания, включающая в качестве самостоятельного направления воспитание основ религиозной терпимости.

Концептуальные основы воспитания религиозной терпимости у студенческой молодежи в условиях развития атеистического по характеру воспитания в целом была ориентирована на решение двух важных противоречий.

Главное идейно-политическое противоречие советского этапа развития педагогических идей воспитания религиозной терпимости у студенческой молодежи было между установкой на недопущение оскорбления чувств верующих (представителей других конфессий) и достаточно жесткой (особенно впервые десятилетия советской власти) атеистической политикой.

Противоречие в педагогической области проявлялось между тенденцией сохранения элементов религиозного воспитания семье в связи с достаточно высоким уровнем религиозности населения и атеистическим характером воспитания студенческой молодежи. Оно выражалось в отсутствии теоретических разработок и опыта профилактики конфликтов на религиозной почве у студентов между представителями различных конфессий, а также между атеистами и верующими.

Формулирование задач («ленинский образец»), на основе которых формировались концептуальные основы воспитания религиозной терпимости у студенческой молодежи осуществлялось государством. Их содержание отражено в произведениях педагогической направленности ведущих идеологов и политических лидеров периода становления советской Н. К. Крупской, В. И. Ленина, А. В. Луначарского, П. А. Красикова, Е. М. Ярославского и др. Перед высшей школой были поставлены следующие задачи воспитания основ религиозной терпимости у студентов в рамках развития атеистического воспитания:

- «сочетать идейную борьбу против религии с укреплением единства верующих и неверующих»;

- содействовать распространению научных знаний в студенческой среде;

- научно, материалистически, с учетом исторических, социальных, культурных и эмоционально-психологических факторов объяснять причины сохранения религиозности;

гией, ни попыток административного запрета религии;

- активно вовлекать студенческую молодежь в процесс коммунистического строительства.

\footnotetext{
Программа РКП (б)//Организация атеистического воспитания. М.: Изд-во политической литературы, 1986.-С.135.
}

Таким образом, содержание воспитания основ религиозной терпимости у студенчества было направлено на реализацию государственных задач и сформулировано в первые десятилетия Советской власти, когда, по мнению А. А. Луначарского «человек воспитывается в интересах социалистического общества. Этим должны определяться и формы, и содержание, и методы работы» ${ }^{5}$.

Особенностью советской педагогики при решении данной проблемы являлась ориентированность на воспитание у молодежи уважительного отношения к конституционным нормам, закрепляющим принцип религиозной свободы в СССР. Идея о воспитании уважительного отношения к чувствам верующих и возможности их свободного проявления в СССР в педагогических трудах советских педагогов не прослеживалась. В большинстве работ методического плана (Н. К. Крупская, В. И. Ленин, Е. М. Ярославский и другие) указывается, что специалисты с высшим образованием должны были способствовать устранению религиозности у населения.

Таким образом, основное содержание воспитания религиозной терпимости у молодежи сохраняло свою актуальность на протяжении всего советского периода истории России. Оно включало не только целевую, но и когнитивную, эмоциональную, нравственно-волевую и деятельностную составляющие, процесс и результаты.

Постараемся проанализировать каждую составляющую данной концепции.

Когнитивная составляющая была ориентирована на развитие научных, идейно-правовых, религиозных знаний у студентов вузов в рамках учебной и внеучебной деятельности.

Анализ теории проблемы позволил сделать вывод, что особое внимание в деятельности вузов уделялось формированию правовой грамотности и материалистического мировозрения.

Развитие правовой грамотности предусматривало знание содержания Декрета СНК «Об отделении церкви от государства и школы от церкви» и Конституции РСФСР (СССР), определяющих основные идеи свободы совести в стране:

- провозглашение и закрепление принципа равенства религий и конфессий в условиях «отделения церкви от государства и школы от церкви»;

- обеспечение свободы религиозной и антирелигиозной пропаганды за всеми гражданами;

- обеспечение свободного исполнения религиозных обрядов, постольку, поскольку они не нарушают общественного порядка и не сопровождаются посягательствами на права граждан Советской Республики 6 . Права верующих ограничивались со стороны госу-

\footnotetext{
Луначарский А.В. О социалистическом воспитании. - М, 1918. С.89.

6 Декрет СНК «Об отделении церкви от государства и школы от церкви» //Русская православная церковь в советское время (1917-1991). Том 2./Сост. Г. Штриккер,-М.:Пропилеи,1994.-С .113, 126.
} 
дарства в вопросе развития знаний о мире религиозного: «Преподавание религиозных вероучений во всех государственных и общественных, а также частных учебных заведениях, где преподаются общеобразовательные предметы, не допускается Республики .

Студенты советских вузов в доступной форме могли овладеть научно- материалистическими знаниями посредством вводимых в учебные планы вузов новых учебных дисциплин. В число дисциплин, заменяющих религиозную составляющую обучения у студентов, в советских вузах были введены: Капитализм и пролетарская революция, Строительство и профсоюзное движение в СССР, История марксизма-ленинизма, Основы марксизма-ленинизма, Введение в диалектический и исторический материализм, Диалектический материализм, Исторический материализм, Основы научного атеизма и другие. ${ }^{8}$

В 1920-30-е годы учебный план курсов подготовки студентов-пропагандистов, большую часть которых составляли студенты вузов, предусматривал углубленное изучение истории и культуры народов СССР: «История народов СССР»- 80 часов, «История ВКП (б) - 180 часов, «Конституция СССР» - 32 часа, «Партийная пропаганда и агитация» - 30 часов 9 . Особое внимание обучающихся акцентировалось на формирование у студенческой молодежи соблюдения прав и свобод гражданина в религиозной сфере.

Данные учебные дисциплины должны были способствовать формированию выпускника, готового осуществлять воспитательную работу в трудовом коллективе по преодолению религиозности и формированию научно-атеистического миропонимания» ${ }^{10}$. Так как они раскрывали основные мировоззренческие вопросы-«о смысле жизни, о подлинных жизненных ценностях, о судьбах человеческого общества, определяли отношения человека к миру и к своему месту в нем» ${ }^{11}$.

Методика преподавания данных дисциплин предполагала совмещение двух противоположных подходов атеистического воспитания: «воинствующего» и умеренного (гуманистического).

Гуманистический характер предполагал воспитание правовой культуры и воспитание религиозной терпи-

Декрет СНК «Об отделении церкви от государства и школы от церкви»//Русская православная церковь в советское время (1917-1991). Том 2./Сост. Г. Штриккер,-М.:Пропилеи,1994.-С .113, 126.

8 Программы кафедры марксизма-ленинизма// Государственный архив Кировской области (ГАКО). ф.Р-1148, оп.1., Д.77, Л.6-7;

Протокол заседания комиссии оргбюро ЦК ВКП (б) по выработке проекта постановления о политико-воспитательной работе в вузах и втузах с материалами//Российский государственный архив социально-политической истории (РГАСПИ). Ф.17.Оп.120, Д.93, Л.9.

9 Учебный план педагогических курсов /2-х летних/ при Вятском Институте имени В.И. Ленина для национальных меньшинств (1920е гг.// Государственный архив социально-политической истории Кировской области (ГАСПИКО) Ф. 129076, Оп.2, Д.152, Л.41.

10 Партийная организация и атеистическое воспитание/Отв. ред.А.Ф. Окулов.-М.:Политиздат, 1975.-С.17.

11 История и теория атеизма. Издание третье, доработанное/Отв. ред.Ф.Г. Овсиенко.-М.:Мысль, 1987.-С.3. мости в рамках изучения учебных дисциплин атеистической направленности в узком смысле. Данный подход предусматривал формирование у студентов системы правовых знаний, содержания принципа свободы совести и осознания своей миссии по искоренению религиозных пережитков в обществе посредством пропаганды научно-технических знаний, принятие идей интернационализма и конституционной идеи равенства перед государством всех людей независимо от национальности и вероисповедания, недопущение оскорбления людей на религиозной почве.

Укрепление идеи о равенстве людей независимо от их религиозной принадлежности также связывалось с развитием знаний о культуре различных этноконфессиональных групп (П. П. Блонский, П. Н. Луппов, С. Т. Шацкий и др.): «Поставить задачу изучения национальной политики, родного языка, истории и этнографии; изучение быта национальностей и популяризацию народного творчества» ${ }^{12}$.

Данная идея внедрялась в практическую деятельность школ и высших профессиональных учебных заведений. Изучение социально-гуманитарных дисциплин учебных планов школ и вузов способствовало воспитанию представлений у студенческой молодежи об особенностях иных национально-религиозных культур и внедрению практики мирного сосуществования в рамках одного коллектива.

Воспитание студенческой молодежи на основе принципа воинствующего атеизма, предполагало формирование непримиримого отношения без исключения ко всем разновидностям религии, теологии, религиозной философии, не нарушающего рамок правового поля. Идея об уважении чувств верующего человека в советский период была не приемлема. Однако, индивидуальную атеистическую работу с верующими рекомендовалось вести на основе «терпения, настойчивости и тактичности» ${ }^{13}$.

Это было одним из способов профилактики конфликтов на религиозной почве.

Таким образом, когнитивная составляющая воспитания основ религиозной терпимости была ориентирована на формирование атеистического (материалистического) мировоззрения, что предполагало развитие нравственно-эмоциональной и волевой сфер у студентов, а именно принятие атеистических ценностей и идеи о недопущении оскорблений людей на религиозной почве.

Умеренные позиции атеистического воспитания и воспитания основ религиозной терпимости проявлялись трудах П. П. Блонский , П. Н. Луппов, А. С. Макаренко, А. П. Пинкевич. В. А. Сухомлинский и др.

Официальная доктрина атеистического воспитания студенчества в СССР не ориентировала на открытую критику религиозных догм и доказательство

\footnotetext{
12 Тезисы работы среди нацмен// Государственный архив Кировской области (ГАКО) Ф 452, Оп.1, Д.95, Л.39.

13 История и теория атеизма. Издание третье, доработанное/Отв. ред.Ф.Г. Овсиенко.-М.:Мысль, 1987.-С.3.
} 
истинности научно-материалистического мировоззрения: «Задача состоит в том, чтобы обеспечить замену религиозных ценностей ориентацией и связанных с ними стереотипов поведения социалистическими идеалами, чувством хозяина своей судьбы, активной жизненной позицией. Нужно учитывать также, что религиозные пережитки бывают связаны с другими пережитками прошлого, такими как национализм, индивидуализм, поэтому атеистическое воспитание необходимо осуществлять в единстве с политическим, трудовым, нравственным, эстетическим воспитанием» ${ }^{14}$.

Государство ориентировало вузы обратить особое внимание на развитие партийной, политико-просветительной и культурно-массовой работы среди студенчества, согласовывая ее с учебной деятельностью. Организации внеаудиторной воспитательной работе в советских вузах придавалось большое значение.

Развитие краеведческих знаний, по мнению С.Т. Шацкого, должно быть направлено на изучение истории родного края, «изучение своей семьи, улицы, родного города, страны, а также народного творчества». Уважение к своей родной культуре обеспечивало уважение к культуре людей, принадлежащих к другим этноконфессиональным группам, населявшим великую Родину ${ }^{15}$.

В советских вузах широко были распространены такие научные кружки, как кружок родиноведения, кружок этнографии, кружок истории местного края, кружок атеизма, кружок интернациональной дружбы и другие ${ }^{16}$.

У студентов сохранялся интерес к экскурсиям в храмы, однако, обращалось внимание не на изучение религиозной составляющей, а на изучение архитектуры ${ }^{17}$.

Особое внимание в советской педагогике 1920-80х гг. уделялось развитию общечеловеческих ценностей (отзывчивости, чуткости, ответственности): «Одним из самых ужасных недостатков современных людей является то, что в них очень мало человечности. Человек должен быть чутким к человеку» (П. П. Блонский $)^{18}$. Концепция национально-патриотического воспитания П.П. Блонского, предусматривала воспитание у молодежи стремления к укреплению социального мира.

Уважение по мнению А. С. Макаренко должно формироваться на примерах из жизни выдающихся людей, демонстрации правильного, с точки зрения общечеловеческих и советских ценностей, поведения молодежи. Актуализируется проблема формирования у рабочей и студенческой молодежи культуры общения в полиэтническом и поликонфессиональном пространстве че-

\footnotetext{
14 Организация атеистического воспитания С.17 120,c.17

15 Шацкий С.Т. Школа для детей и дети для школы?//На путях к новой школе.-1922.-№1.-С.23-27.

16 Отчеты и доклады о работе факультетов. Научных и художественных кружков: список кружков// Государственный архив Кировской области (ГАКО). ф.Р-1148,оп.1, Д.77, Л.110.

17 Отчеты и доклады о работе факультетов. Научных и художественных кружков: список кружков// Государственный архив Кировской области (ГАКО). ф.Р-1148, оп.1, Д.77, Л.110

18 Блонский П. П. Избранные педагогические сочинении. - М.: Педагогика, 1979. В 2-х томах.-T.1.-С.58-59.
}

рез развитие патриотических чувств любви и гордости за свою Родину: «Несмотря на многонациональность и разбросанность на огромной территории, изъясняясь на сотне языков, он удивительно дружно сбился в единый народ, монолитная воля которого - явление почти чудесное, ни в какую эпоху, ни в каком месте история не видела ничего подобного и не могла видеть» ${ }^{19}$.

А.С. Макаренко настраивал педагогов на гуманные способы борьбы с религиозными пережитками. Главным методом он считал убеждение молодежи в нерациональности религии: «Христианская этика не интересовалась вопросами труда и трудовой честности. Посмотрите на птиц небесных. Они не сеют, не жнут, не собирают в житницы, а живут». У нас труд есть дело чести, дело доблести, геройства. В нашем обществе труд является не только экономической категорией, но и категорией нравственной. То, что считалось нормальным, - нищенство, попрошайничество, беззаботность, - у нас должно считаться прямым преступлением» ${ }^{20}$. Теория коллектива, сформулированная А. С. Макаренко, стала одной из ключевых методических основ организации атеистического воспитания в советский период в вузах и различных организациях.

Радикальный подход на основе идей «воинствующего безбожия» был представлен в педагогических взглядах Е. М. Ярославского, которые противоречили советскому конституционному принципу «свободы совести», а также традиционным представлениям о нравственности и гуманности. Педагог ввел понятие такой педагогической категории как «ненависть». В работе «О воспитании чувства ненависти» он писал: «Нашей природе революционеров противно лицемерное христианское учение: если тебя ударят по правой щеке, подставь левую. Только разоблачив социальный вред для рабочих и крестьян этих и подобных поповских проповедей, мы могли бы поднять на борьбу против царя, помещиков и капиталистов <... . Огромную роль будет играть воспитание глубокой любви к социалистической Родине, коммунистической партии и самой непримиримой ненависти к врагам коммунизма» ${ }^{21}$.

Содержание воспитания религиозной терпимости у студенческой молодежи определялось в соответствии с поставленными им целями. Е. М. Ярославский ориентировал на развитие студенческих молодежных организаций «воинствующего безбожия»: «У нас есть целый ряд обществ, которые должны соединить свои усилия: и спортивные, и такие, как Осоавиохим, Союз воинствующих безбожников» ${ }^{22}$.

По мнению педагога и политического деятеля пер-

\footnotetext{
19 Макаренко А.С. Педагогические сочинения. - М.: Изд-во академии педагогических наук РСФСР, 1948.-С.45.

20 Макаренко А.С. Педагогические сочинения. - М.: Изд-во академии педагогических наук РСФСР, 1948.-С.57.

21 Е.М.Ярославский// Российский государственный архив социально-политической истории (РГАСПИ) Ф. 89 Оп.9, Д.11, Л.1,34.

22 Выступление о воспитании молодежи ....//Российский государственный архив социально-политической истории( РГАСПИ) Ф. 73, Оп.9, Д.113, Л.1,34
} 
вых десятилетий советской власти Е.М. Ярославского, принцип равенства людей независимо от национальной и религиозной принадлежности способствует и формированию единства идеологических революционных взглядов, и новой социальной унифицированной общности - советского человека. Отмирание религии исключало и возможность конфликтов на религиозной почве.

Е. М. Ярославский принимал активное участие в учебном процессе и воспитательной работе Московского государственного университета. В беседах с молодежью советский общественный деятель, педагог, теоретик и практик организации атеистической работы среди молодежи Е. Ярославский определил ценностный, мотивационный и деятельностный компоненты атеистического воспитания и исключения религии из жизни молодежи: «Мы еще очень бедны. То, что мы делаем для своих детей, детей рабочего класса только начало этого великого дела, которое должно в корне изменить условия жизни и навыки. Советские учреждения должны воспитывать нового человека. Основой этого воспитания должно быть:

- Трудящиеся всех народов, всех наций, всех стран дети одного класса, братья труда.

- Воспитание крепкой воли, которая не подавлена религией, которая умеет побеждать природу, организованный труд, новая техника» ${ }^{23}$.

Таким образом, педагог рассматривал профилактику социальных конфликтов с помощью развития идеи равенства людей и научного мировоззрения.

Объединяет эти два подхода идея о развитии деятельностного участия студентов в воспитательном процессе. Особенностью и результатом деятельностного участия студентов в деле атеистического воспитания и воспитания основ религиозной терпимости виделось педагогами в их активной деятельности по развитию атеистического мировоззрения и основ религиозной терпимости у других.

Сторонники деятельностного подхода к воспитанию молодежи (А. В. Луначарский, А. С. Макаренко, А. П. Пинкевич, В. Н. Шульгин и др.) обосновывали эффективность таких направлений развития деятельностного компонента у студенчества, как активное участи в социалистическом строительстве, развитие самоуправления, укрепление дисциплины, формулирование перспектив развития коллектива.

Реализация государственного заказа на активное вовлечение студенчества в воспитание советских граждан осуществлялось в рамках следующих направлений работы: организации общественных факультетов, клубов и кружков, создание студентами университетов культуры на предприятиях, в школах, учреждений дополнительного образования молодежи, участие в выпуске газет и журналов.

\footnotetext{
23 Выступление о воспитании молодежи// Российский государственный архив социально-политической истории ( РГАСПИ)Ф.89, 73, Оп.9, Д.113, Л.3
}

Анализ педагогической практики высших профессиональных учебных заведений и молодежных студенческих организаций (включающих и комсомольские ячейки) советского периода показывает наличие активной работы студенческой молодежи с населением регионов.

Так, например, студент педагогического института и молодой педагог должны были вести с населением активную «Общественно-организационную, культурно-просветительскую работу» ${ }^{24}$. В Вятском учительском институте были организованы специальные курсы для подготовки учителей для работы в марийских и удмуртских школах. Содержание учебно-воспитательного процесса ориентировало на формирование уважительного отношения к представителям иных религиозных культур и развитие атеистического мировоззрения ${ }^{25}$. В начале 1920 -х гг. в Вятском учительском институте работало более двадцати кружков различной направленности. Часть кружков - это истории местного края, кружок изучения марксизма - ленинизма как экономической и философской доктрины, кружок этнографии Вятского края, ставили задачу формирования материалистического мировоззрения, идеи равенства людей независимо от религиозной принадлежности ${ }^{26}$. Отсутствие теоретических наработок восполнялось идейно-политическим заказом в форме инструкций и предписаний по организации атеистического воспитания и профилактике конфликтов в высших профессиональных учебных заведениях на национальной и религиозной почве.

Базой для организации воспитательной работы со студенческой молодежью в рамках нового направления воспитательной работы являлась инструкция. Вузы строили свою деятельность по атеистическому воспитанию молодежи фактически целиком на основе четких инструкций, получаемых от центральных органов. Инструктивные письма для организации педагогической работы среди студенческой молодежи по различным направлениям составлялись на научной основе, опирались на учет особенностей региональной этноконфессиональной среды, анализ уровня религиозности и политической активности населения. Студенты - пропагандисты должны были следовать инструкциям, учитывающим особенности традиционной культуры регионов.

Актуальным для этого периода оставался принцип «демократического централизма», предполагающий строгую подчиненность вышестоящим инстанциям. Инструкция по организации ячеек «Союза безбожников СССР» определяла ориентацию студентов на активное участие в его работе: Средства изыскивать

\footnotetext{
24 Схемы, учебные планы, выписки из журналов заседаний правления института 1924-1925 гг.// Государственный архив Кировской области (ГАКО). Ф. Р-1148, Оп.1, Д.212, Л.92.

25 Государственный архив Кировской области (ГАКО). Ф. Р-1148, Оп.1, Д.77. Л.110-111.

26 Госуда,рственный архив Кировской области (ГАКО). Ф. Р-1148, Оп.1, Д.77. Л.110-111.
} 
самостоятельно для устройства уголка безбожника, читальни, библиотеки, вечеров и прочее. Путем членских взносов, единовременных взносов, продажи литературы. Каждый член ячейки содействует личным трудом» ${ }^{27}$.

Широко использовалось влияние средств масоовой информации (газет, журналов, радио) на студенческую молодежь. В советских газетах и журналах печатались частушки, песни, сценарии антирелигиозных мероприятий с целью их активного внедрения в учебно-воспитательный процесс школ и вузов. Содержание пропагандируемого молодежного фольклора настраивало на принятие советских ценностей:

«Не ругай меня, мамаша:

Прошли темные года.

Пионера (комсомольца) верить в Бога

Не заставишь никогда»

Как показывает анализ отечественного опыта воспитания культуры межконфессиональных отношений, поведения людей в сфере религиозных отношений (атеизма, религиозности и др.), к числу эффективных эмоциональных стимулов можно отнести использование следующих средств: литературы и истории (положительные исторические примеры межконфессиональных отношений, взгляды великих людей и религиозных деятелей на важность сохранения межконфессионального мира и др.), общественного мнения, примера педагога и старшего, средств искусства, «вживание в иную религиозную культуру» (общение с представителями иных конфессий и духовенством в местах их локальной дислокации), участия в народно-религиозных праздниках, юмор.

Реализации государственной политики в религиозном направлении, поддержанию социального мира способствовали особые для советского периода формы и методы контроля за ее проведением на местах, в конкретных вузах. Оценочный компонент выражался в государственном контроле за проведением воспитательных мероприятий со студенческой молодежью. Контролирующие функции первоначально осуществляли местные отделы ОГПУ. Данный подход давал свои положительные результаты. Посещение церквей становится меньше и ведется лишь за счет зажиточного элемента, женщин и стариков. Молодежь, хотя и далеко не вся, но в значительном большинстве признает все церковные обряды поповскими выдумками и обманом. По всем уездам подмечено, что молодежь лишь только под влиянием своих родителей продолжает наружно выполнять религиозные обряды, но в большинстве к религии относится безразлично.

Среди глубоко верующих представителей населения, отмечались и антисоветские взгляды. Даже в начале 1940-х годов часть православных верующих продолжала считать себя гражданами Российской Им-

\footnotetext{
27 Исполбюро: Инструкция по организации ячеек союза безбожников СССР// Государственный архив Кировской области (ГАКО). Ф.452., Оп.1Д.93, Л.4.
}

перии, а не СССР. Они ориентировали молодежь на мероприятия, способствующие нарушению социальной стабильности: «Отказ от службы в армии, учеба в безбожных школах, состояние в колхозах и коммунах, участие в выборах». С целью профилактики негативных проявлений на религиозной почве органами советской власти использовался метод наказания, вплоть до тюремного заключения на длительный срок.

Период Великой Отечественной войны - это время «оттепели» в государственно-церковных отношениях. На протяжении всего советского периода, особенно первых десятилетий советской власти продолжалась борьба между государством и церковью, верующими за умы и души молодежи. На меры атеистического характера со стороны государства всегда находились контрмеры со стороны церкви и простых верующих. Несмотря на выраженные успехи советского государства, оно не стало победителем в этой борьбе. Крепость провинциальных религиозных традиций, семья и вера каждого отдельного человека не позволили искоренить религию и уничтожить церковь.

Отмечается определенное обращение к идеалам, составляющим суть традиционной парадигмы воспитания: народный патриотизм, помощь государству в трудную минуту, взаимопомощь друг другу, милосердие.

Русская православная церковь рассматривалась государством, как социальный институт, способствующий консолидации и мобилизации народа на борьбу с внешним врагом. Русская православная церковь с первых дней войны официально поддерживало государство в деле борьбы с врагом. Среди верующих развернулась кампания по сбору средств на нужды фронта. В стране началось лимитированное открытие храмов. Данный процесс нашел горячий отклик в среде верующих, способствовал определенному повышению авторитета советской власти в глазах верующих. Школа, вузы, молодежные организации должны были перейти от жесткой критики религии и церкви к мягким методам научной пропаганды и антирелигиозной агитации, направленной на уменьшение роста религиозности среди молодежи.

Светский досуг молодежи противопоставлялся религиозным мероприятиям: «В церквях создаются большие хоры, и мы должны создать большие хоры, чтобы, кто хотел, мог петь, а кто хотел, мог слушать» ${ }^{28}$.

Единение народа, стимулирование общего патриотического чувства у народа способствовало тому, что религиозные различия уходили на второй план. Воспоминания очевидцев наиболее ярко отражают характер межконфессиональных отношений в Кировской области в военный период и отношение народа к антирелигиозной политике советской власти и являются достоверным источником историко-педагогического плана, отражающим особенности семейного воспитания и

28 Государственный архив социально-политической истории Кировской области (ГАСПИКО), Ф.1290, Оп.10, Д.143,Л.270. 
влияния этноконфессиональной среды на воспитание подрастающего поколения.

В годы Великой Отечественной войны в процессе организации воспитания молодежи в контексте общегосударственной идеологии прослеживалось обращение к парадигме традиции. Народно-патриотические чувства, народный коллективизм и чувство взаимопомощи в трудный период, которые отодвигали на второй план религиозные различия, способствовали консолидации народа в годы войны на фронте и в тылу. Кировская область, являясь тыловым регионом, от которой во многом зависело снабжение фронта, устройство огромной массы эвакуированных, являлась примером традиционного мирного межконфессионального сосуществования.

Тенденция «соперничества атеистического и религиозного» воспитания молодежи в советский период изучалась уже в рамках современного периода развития историко-педагогического знания (А. Г. Балыбердин, А. Г. Поляков, Л. Г. Сахарова, Т. А. Чумаченко, Н. А. Шабалин и др.).

Гуманизация государственных подходов к процессу укрепления социальной стабильности начинается 1950-70-е гг., с развитием демократических идей, появлением теоретических разработок реализации религиозной политики и поддержания конфессионального мира в СССР в контексте идей оформления послевоенного мироустройства. Более четкая регламентация правовых оснований свободы совести и ее границ была осуществлена в международном плане в 1948 г., что повлияло на формирование законодательства о религии в СССР и способствовало переходу к мягким формам атеистической работы в воспитании подрастающего поколения. Резолюцией 217 А (III) Генеральной Ассамблеей ООН была принята Всеобщая декларация прав человека, послужившая моделью при определении стандартов прав человека для новейших конституций, принятых во многих странах мира, в том числе, и в СССР. Статья 18 Всеобщей декларации прав человека гласит: «Каждый человек имеет право на свободу мысли, совести и религии; это право включает свободу менять свою религию или убеждения и свободу, исповедовать свою религию или убеждения как единолично, так и сообща с другими, публичным или частным порядком в учении, богослужении и выполнении религиозных и ритуальных порядков».

Начинает проявляться темпоральность, то есть постепенно наряду с традиционной религиозной культурой сформировалась новая советская безрелигиозная культура, которая к концу 1970-х годов приобретает черты традиционности. Образовательно-воспитательный процесс осуществляется вне религии. Религиозное воспитание остается лишь частью семейного воспитания молодежи. Молодежь в рамках культуры повседневности придерживается светской обрядности. Советские традиции, праздники, такие, как празднование годовщины Октябрьской революции (7 ноября), 1мая - День Международной солидарности трудящихся, 8-е марта - Международный женский день, по сути, имели интернациональную направленность.

Революционная сущность постепенно заменялась общежитейской, ориентирующей на позитивное проведение досуга, актуализацию эмоциональной сферы и исторической памяти (В. А. Сухомлинский). Педагог апеллировал к методам формирования нравственных чувств, актуальным и для современной ситуации: убеждение посредством беседы, личный пример. Идеи духовно-нравственного воспитания молодежи в советском обществе в контексте общемировых принципов общественного развития разрабатывал В. А. Сухомлинский ${ }^{29}$.

В итоге почти полувековое формирование атеизма и интернационализма привело к постепенному вытеснению религии из жизни, особенно студенческой молодежи.

В массовых молодежных воспитательных мероприятиях интернационального-поликультурного плана уже не делается яркого акцента на демонстрацию сути этноконфессиональных культур. Этот факт подтверждает анализ ряда методических разработок мероприятий по воспитанию чувства интернационализма на фоне которого формировалось уважительное отношение к представителям различных социальных общностей.

В культуре советской повседневности 1970-80x годов не прослеживается выражение молодежью своей религиозной идентичности. Педагоги периода 1970-начала 1990-х гг. определяли религиозную культуру на роль воспитания эстетических чувств, тем самым укрепляя отношения в конфессиональном мире через идею связи культур народов СССР. Особое внимание педагоги этого периода обращали на формирование молодежного коллектива, который невозможен без уважительного отношения его членов друг к другу.

Атеистическое воспитание осуществлялось в мягких формах формирования материалистического мировоззрения: массовые интернациональные праздники, конкурсы творческих работ по атеистической тематике, экскурсионные поездки в другие города и зарубежные страны.

Проиллюстрируем атеистическое и интернациональное направления учебно-воспитательной работы некоторыми примерами из практики вузов города Кирова (Кировская область). Широко популяризировалось и имело огромный успех массовое студенческое мероприятие в г. Кирове «Мы патриоты-интернационалисты», посвященное 60-летию ВЛКСМ и XI Всемирному фестивалю молодежи и студентов. Программа включала массовое шествие представителей всех районов, национальных творческих молодежных коллективов и фестиваль молодежного творчества ${ }^{30}$.

\footnotetext{
29 Сухомлинский В.А. Как воспитать настоящего человека.- М.: Педагогика, 1989.

30 Государственный архив социально-политической истории Кировской области (ГАСПИКО), Ф.84.Оп.7, Д.111, Л.6-7]
} 
В вузах г. Кирова активизировалась атеистическая работа кружков при обществоведческих кафедрах ${ }^{31}$. В Кировским государственном сельскохозяйственном институте были организованы выставки: «Новый шаг по пути к коммунизму», «Родная земля», «Наука и религия» ${ }^{32}$.

В 1970-е годы особой популярностью пользовались ознакомительные поездки студентов в зарубежные страны. В плане атеистического воспитания осуществлялся сравнительный анализ достижений, подвергалась критике религиозная мировоззренческая позиция иностранных студентов, которая воспринималась как негативный элемент характеристики выпускника вуза. В отчете о поездке в Польшу студентов Кировского государственного педагогического института имени В. И. Ленина отмечалось: «Анжей Кжижановский студент последнего курса экономического факультета, неплохо владеет русским языком, грамотен, начитан. Однако, политически-безыдейный, посещает костел». Вопросы межнациональных и межконфессиональных отношений являлись темой для дискуссий кировских студентов с иностранными студентами при поездках в Данию, Румынию, Францию: «Существует ли в учебных заведениях СССР расовая дискриминация?», «О положении негров в СССР», «На каких языках ведется преподавание в вузах?», «Существуют ли в СССР еврейские погромы?» и др..$^{33}$

Атеистическая работа, светский характер общественной жизни постепенно исключали проявлению населением религиозных чувств, что и являлось своего рода профилактикой межконфессиональных конфликтов. В обыденной жизни люди руководствовались

\footnotetext{
31 Государственный архив социально-политической истории Кировской области (ГАСПИКО), Ф.94, Оп. 1, Д.2,18,40.

32 Государственный архив социально-политической истории Кировской области (ГАСПИКО), Ф.94, Оп. 1, Д.2,18,40.

33 Государственный архив социально-политической истории Кировской области (ГАСПИКО), Ф.85, Оп.13, Д.111, Л.137.
}

традиционными нормами уважительного отношения друг к другу, которое подкреплялось и требованиями советской педагогики.

Таким образом, анализ педагогической и социально-политической практики СССР и отдельных регионов по воспитанию культуры межконфессиональных отношений в советский период позволяет сделать ряд выводов:

- в советский период истории России внимание уделялось воспитанию у молодежи социально-личностных качеств, значимых для стабильного развития общества и государства в целом в русле коммунистической идеологии;

- воспитание культуры межконфессиональных отношений предусматривалось в русле формирования идей о всеобщем равенстве людей независимо от национальной и религиозной принадлежности, закрепленных законодательно;

- развивалась идея о широкомасштабном сотрудничестве молодежи, независимо от конфессиональной и национальной принадлежности, в деле строительства коммунизма;

- понятие религиозной принадлежности постепенно размывалось и утверждалось общее для всех понятие «советский гражданин»;

- культура повседневности и сохранение религиозности у значительной части населения в явной и скрытой формах предполагали формирование у молодежи как наиболее активной группы населения основ культуры межконфессиональных отношений косвенными методами. Особое внимание уделялось развитию атеистического мировоззрения;

- вырабатывались специфические региональные методики интернационального воспитания, направленного и на формирование основ культуры межконфессиональных отношений соответствующих декларируемым демократическим нормам «свободы совести» и атеизма.

\section{Литература}

Блонский П. П. Избранные педагогические сочинения. - М.: Педагогика, 1979. В 2-х томах

Декрет СНК «Об отделении церкви от государства и школы от церкви» //Русская православная церковь в советское время (1917-1991). Том 2./Сост. Г. Штриккер,-М.:Пропилеи, 1994

Жиромская В. Б. Религиозность народа в 1937 году (по материалам Всесоюзной переписи населения)// Исторический вестник.2000. №5.-С.130-135

История и теория атеизма. Издание третье, доработанное/Отв. ред. Ф. Г. Овсиенко.-М.:Мысль, 1987.

Луначарский А. В. О социалистическом воспитании. M, 1918
Макаренко А. С. Педагогические сочинения. - М.: Издво академии педагогических наук РСФСР, 1948

Отчеты и доклады о работе факультетов. Научных и художественных кружков: список кружков// ГАКО ф.Р-1148, оп.1, Д.77, Л.110

Отчеты и доклады о работе научных и художественных кружков: протокол кружка «Родиноведение» (1920-1921 гг.)//Государственный архив Кировской области (ГАКО). Ф.Р-1148,Оп.1, Д. 77, Л.150

Партийная организация и атеистическое воспитание/ Отв. ред. А. Ф. Окулов. - М.: Политиздат, 1975

Программа РКП (б)//Организация атеистического 
воспитания. - М.:Изд-во политической литературы, 1986

Программы кафедры марксизма-ленинизма//ГАКО ф.Р -1148, оп.1., Д.77, Л.6-7

Протокол заседания комиссии оргбюро ЦК ВКП (б) по выработке проекта постановления о политико-воспитательной работе в вузах и втузах с материалами// Российский государственный архив социально-политической истории (РГАСПИ). Ф.17. Оп.120, Д.93, Л.9.

Сухомлинский В. А. Как воспитать настоящего человека.- М.: Педагогика, 1989.

Схемы, учебные планы, выписки из журналов заседа- ний правления института 1924-1925 гг.// Государственный архив Кировской области (ГАКО). Ф.Р1148, Оп.1, Д.212, Л.92.

Тезисы работы среди нацмен// Государственный архив Кировской области (ГАКО). Ф 452, Оп.1, Д.95, Л.39

Учебный план педагогических курсов /2-х летних/ при Вятском Институте имени В. И. Ленина для национальных меньшинств (1920-е гг).// Государственный архив социально-политической истории Кировской области (ГАСПИКО). Ф. 129076, Оп.2, Д.152, Л.41]

Шацкий С.Т. Школа для детей и дети для школы?//На путях к новой школе.-1922.-№1.-С.23-27.

Rozmiar artykułu: 1 arkusz wydawniczy 
ISSN 1508-7719

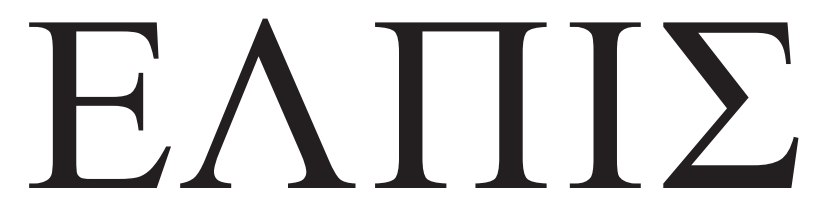

CZASOPISMO TEOLOGICZNE KATEDRY TEOLOGII PRAWOSŁAWNEJ UNIWERSYTETU W BIAŁYMSTOKU

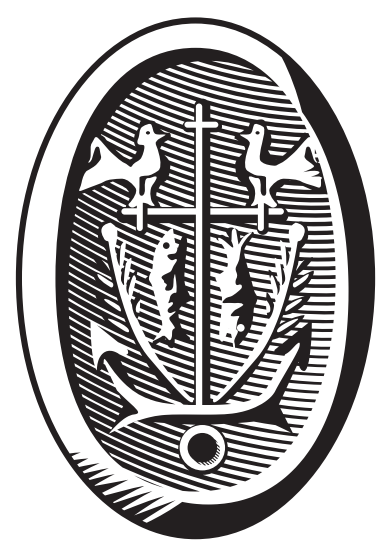

ADRES REDAKCJI

15-097 Białystok, ul. M. Skłodowskiej-Curie 14 tel. 85 745-77-80, e-mail: redakcja@elpis.edu.pl www.elpis.uwb.edu.pl 